\title{
Et İşleme Tesislerinde Kullanılan Bıçak Sterilizatörünün Tasarımı Üzerine Deneysel Bir Çalışma
}

\author{
Gültekin BASMACI (D) 1*, İbrahim BUTGÜL (iD)2 \\ ${ }^{1}$ Burdur Mehmet Akif Ersoy Üniversitesi, Mühendislik Mimarlık Fakültesi, Burdur \\ ${ }^{2}$ Burdur Mehmet Akif Ersoy Üniversitesi, Fen Bilimleri Enstitüsü, Burdur \\ Geliş Tarihi (Received): 01.06.2021, Kabul Tarihi (Accepted): 29.07.2021 \\ $\square$ Sorumlu Yazar (Corresponding author ${ }^{*}$ ): gbasmaci@mehmetakif.edu.tr \\ (C) +902482132715 등 +902482132704
}

ÖZ

Et işleme tesislerinde iş hijyeni çok önemlidir. Bu nedenden dolayı kasapların her işlem öncesi ve sonrasında kesim bıçaklarını dezenfekte etmesi gerekmektedir. Bu çalışmada ani su ısıtıcısının, farklı güçteki alüminyum plakaya konumlanmış olan çubuk rezistanslar ve termostat kontrol sistemi ile suyu istenilen sıcaklığa en kısa sürede çıkarmak ve belirle bir sıcaklıkta sabit tutmak amaçlanmıştır. Enerjiyi doğru kullanarak ideal su sıcaklığını kullanım açısından en uygun noktaya çıkarmak hedeflenmiştir. Su sıcaklığının termostat yardımı ile kontrol altında tutulması için mekanizma kurulmuştur. Alüminyum plaka içine yerleştirilmiş çubuk rezistansların $1 \mathrm{~kW}, 1,5 \mathrm{~kW}$ ve $2 \mathrm{~kW}$ güçlerinde çalıştırarak deneysel sonuçlar elde edilmiştir. AISI 304 kalite paslanmaz gövdenin altına konumlandırılmış alüminyum plaka ısı transferinde taşınım yolu ile homojen bir şekilde suyu ısıttığı gözlenmiştir. Deneylerden elde edilen sonuçlar belirlenen parametreler göre karşılaştırımıştır. Yapılan deneyler sonucunda $2 \mathrm{~kW}$ gücündeki çubuk rezistansın daha kısa sürede istenilen sıcaklığa ulaştığı gözlenmiştir.

Anahtar Kelimeler: Alüminyum plaka, ani su ısıtıcı, çubuk rezistans

\section{An Experimental Study on the Design of a Knife Sterilizer Used in Meat Processing Plants}

\begin{abstract}
Occupational hygiene is very important in meat processing plants. For this reason, butchers need to disinfect the cutting blades before and after each procedure. In this study aimed that the kettle is suddenly intended to remove the water as soon as possible to the desired temperature and keep it stable at a certain temperature with the rod resistors and thermostat control system positioned on the aluminum plate of different power. It is also aimed to increase the ideal water temperature to the optimal point of use by using the energy correctly. A mechanism has been created to keep the water temperature under control with the help of a thermostat. Experimental results were obtained by operating the rod resistors placed in aluminum plate at $1 \mathrm{~kW}, 1.5 \mathrm{~kW}$ and $2 \mathrm{~kW}$. It has been observed that the aluminum plate positioned under the AISI 304 quality stainless body heats the water homogeneously by the heat transfer by convection. The results from the experiments were compared according to the determined parameters. As a result of the experiments, we were observed that the rod resistance with a power of $2 \mathrm{~kW}$ reached the desired temperature in a shorter time.
\end{abstract}

Keywords: Aluminum plate, instant water heater, rod resistance 


\section{GíRiş}

Tasarım intiyacının, insanoğlunun var oluşu ile birlikte doğduğu düşünülmektedir. Bir amaç doğrultusunda herhangi bir elektrikli ani su ısıtıcısı, Isı elemanı ve açma-kapama termostatı olan iki parçadan oluşur. Isı kaynağı elektrik gücü suyu ısıtmak için tasarlanmıştır. Sisteme entegre edilen termostat ile suyu istenilen SIcaklığa getirecektir. Su sıcaklığını $100^{\circ} \mathrm{C}$ getirmek için termostat ayarı son seviyede olması gerekmektedir. Ani su ısıtıcı yalnızca suyu kaynatmaya hizmet eder (Çakar, 2021).

Yeni ürün, eskiyi değiştirmek veya geliştirmek adına bir tasarı oluşturmak insanoğlunun her daim gerçekleştirdiği bir eylemi olmuştur. Evlerde kullanılan ev aletlerinin genellikle fikir başlangıcı, keşif veya bir intiyaç sonucu ortaya çıkmıştır. Farklı şekillerde kullanılan su ısıtıcılar yüz yıllardır hayatımızdadır. Elektrikle ısıtılan ilk patent yiyecekler için 1879 'da çıkarıldı. 1894'te elektrikli su ısıtıcıları Chicago'da başlangıçta tehlikeli olan, elektrikli su ısıtıcılarının kendini doğrudan su ısıtıcısı tabanının altına monte edilmiştir. 1922'den sonra verimliği arttırmak için ve daha güvenli bir ısıtma sağlamak için suyun içine ısıtıcı daldırılarak tasarlanmıştır (Batchelor, 1994).

Bir diğer çalışmada ise, termal nanoimprint litografi süreçleri için ısıtma ve soğutma aracı olarak kullanılan, özel olarak düşünülmüş, bir plakanın termal performansı üzerine sayısal bir çalışma yapılmıştır. 240x240x20 mm ölçülerine sahip ısıtma plakasında bir dizi çubuk tipi rezistans ile ısıtma-soğutma kanalları mevcuttur. Yüksek kalıplama basıncına dayanması için paslanmaz çelik malzeme seçilmiştir. Isıtma plakasının hem ısıtma, hem de soğutma fazlarındaki termal davranışını tahmin etmek için sayısal bir model kullanılmıştır. Nanoimprint ekipmanına ait geniş alanlı bir ısıtma plakasının termal tasarımını yapmak için, incelenecek model seçilmiştir. Isı boruları olan ve olmayan, doğrudan ve dolaylı soğutma yöntemlerini kullanarak bir soğutma modeli önerilmiştir. Ayrıca, küçük bir ısıtma plakası oluşturulmuş ve önerilen modelin geçerliliğini doğrulamak için deneysel ve hesaplama analizleri yapılmıştır. Paslanmaz çelikten (AISI 304) geniş alanlı bir ısıtma plakasının genleşmesi durumunda, ortaya çıkabilecek sorunları çözmek için çubuk tipli rezistanslar ısı boruları yönünde sokulmuştur. Sonuç olarak, ısıtma hızı $40^{\circ} \mathrm{C} /$ dakika ve sıcaklık homojenliği, maksimum çalışma sıcaklığı olan $200^{\circ} \mathrm{C}$ 'nin \%1'inden azdır. Soğutma için, basınç düşünüldüğünde ve uçlar için soğutucu madde olarak hava kullanıldığında, $20^{\circ} \mathrm{C} / \mathrm{dk}^{\prime}$ lık bir soğutma hızı ve maksimum sıcaklığa bağlı olarak $13,2^{\circ} \mathrm{C}$ 'den az (\%7'den az) termal performans elde edilmiştir. Elde edilen sonuçlar deneysel sonuçlarla benzerlik izlenmiştir (Park ve Lee, 2019).

Geleneksel olarak "hijyen" terimi temizlikle eşleşmiştir, ancak bu terim çok daha geniş kapsamı olan bir kavramdır. Sağlık tanrısı anlamına gelen "Hygeia" kelimesinden türetilen hijyen, "Sağlığı elde etmek için uyulması gereken kurallar ve uygulamalar" şeklinde tanımlanmaktadır. Bu tanıma göre gıda hijyeni, halk sağlığını korumak için gıda ve gıda üretimi ile ilgili uyulması gereken tüm kurallar ve uygulamalar olarak ifade edilebilir. Codex Alimentarius Commission (CAC) gida hijyenini; "Gıda üretim ve tüketim zincirinin her prosesinde, gıda güvenliğini ve yasal mevzuata uygunluğunu sağlamak için uyulması zorunlu olan bütün koşullar ve önlemler" olarak tanımlamaktadır (Motarjemi, 2016).

Gıda hijyeni, herhangi bir gıda maddesinin temizliği ve hastalık yapan etkenlerden tamamen arındırılmış olması anlamına gelmektedir. Tüketilen gıdalar, 6 gıdayı tüketen insanların hastalanmasına neden olmamalıdır. Gıda hijyeni uygulamaları; patojen mikroorganizmalardan kaynaklanan gıda enfeksiyon ve intoksikasyonlarının önlenmesi yoluyla halk sağlığının korunmasına, gıda kökenli hastalıklara ilişkin tedavi ve işgücü kayıplarının en aza indirilmesine, gıdalarda bozulma ve kalite düşüklüğüne yol açan faktörlerin kontrol altına alınması ve önlenmesi yoluyla da kalite güvenliğinin sağlanarak gıda kayıplarının önlenmesine hizmet etmektedir (Tayar, 2014).

Üretimde etkin bir hijyen kontrolünün sağlanması için, işletmede görevli yönetici kadrosu da dahil olmak üzere bütün personelin hijyen konusunda eğitimli olması gerekmektedir. Geçmişte görülmüş ve halen de görülmekte olan gıda kaynaklı epidemik salgınlar, daha çok gıda hijyeni ile ilgili temel prensiplerin bilinmemesi veya uygulanmamasından kaynaklanmaktadır. Hazır yemek endüstrisinde gözlemlenen eksikliklerin çoğunun, işletmelerde çalışan personelin eğitim ve bilgi eksikliği ile 7 işletmedeki yetersiz temizlik ve dezenfeksiyon uygulamalarından kaynaklandığı bildirilmiştir. Bu nedenle, toplu beslenmeye yönelik yiyecek üretiminde görülebilecek risklerin en aza indirilebilmesi veya tamamen ortadan kaldırılabilmesi için bu tür işletmelerdeki hijyen uygulamalarının titizlikle gerçekleştirilmesi gerekmektedir (Sayın, 2007; Garayoa ve ark., 2011).

Gıda işletmeleri, kapasiteleri, yatırım maliyetleri ve teknik detaylara göre farklılık gösterseler de hizmet sunumu konularında ve hijyen davranışı boyutunda olan teknik birimlerdir. Çünkü hijyen, sektör için büyük bir 
önem taşımaktadır. Gıda işletmelerinde, gıda zehirlenmesi ve salgın hastalık olaylarının olması istenmez (Sökmen, 2003). Bunun yanında; gıda sektörü kaynaklı hastalıkların \%20'si çalışan personelin hijyen konusunda yetersiz kaldığı görülmektedir (Bilici, 2007). Hijyen konusunda güvenirliği dikkat çekilmekte olup (Ural, 2007), gıda üretiminin tüm aşamalarında hastalıkların önlenmesi için personellerin hijyen konusunda sürekli eğitim almaları gerekmektedir (Akbulut, 2010). Gıda hizmet biriminde üretilen gıdaların güvenilirliği, işletmedeki personelin temizliğinden emin olmasıyla başlar (Bilici, 2008). Bu sebepten dolayı gıda üretiminde çalışan personel insan sağlığı açısından önemli sorumluluklara sahiptir. İşletme personellerinin kişisel bakımının yanı sıra, özellikle gıdalarla temas durumlarında el, vücut temizliğinin yanında, iş elbisesi ve üretimde kullanılan ekipmanlarında hijyenik olması gerekir (Yaman ve Özgen, 2007). Sharif ve ark. 2013 yaptıkları araştırmada, gıda tesislerinde çalışan personellerin sıklıkla yaptığı hijyen hatalarını incelediğinde gıdalara çıplak elle dokunma, ellerin bol suyla yıkanmaması, işleme veya hazırlama araç gereçlerin ya da mutfak aletlerinin yetersiz aralıklarla temizlenmesi ve gıdaların patojen (mikroorganizma) bulaşmış kişi/kişiler tarafından hazırlanması ile ilişkilendirmektedir (Boot ve Cairncross, 1993; Atasever, 2000; Altınel, 2009).

Bu çalışmada istenilen sürede suyu ısıtarak ve sabit sıcaklıkta tutarak kasap bıçaklarının dezenfekte edilmesi amaçlanmıştır. Et işleme tesislerinde kullanılan bıçakların her işlemden önce ve sonra dezenfekte edilmesi gerekmektedir. Yapılacak olan deneysel çalışmalar AISI 304 kalite paslanmaz bir gövdenin zeminine monte edilmiş alüminyum plakanın içine yerleştirilmiş çubuk rezistanslar yardımı ile yapılacaktır.

\section{MATERYAL VE YÖNTEM}

Bu çalışmamızda AISI 304 kalite paslanmaz gövdenin altına konumlandırılmış ve alüminyum plaka içine yerleştirilmiş çubuk rezistans tasarımı yaparak $1 \mathrm{~kW}, 1,5$ kW ve 2 kW güçlerinde çalıştırarak suyu en kısa sürede istenilen sıcaklığa ulaştırmak hedeflenmiştir. Yapılan çalışmadan elde edilen veriler, grafikler ve tablolar halinde karşılaştırılmıştır (Aktaş, 2016).

Deneyde kullanılan çubuk rezistanslar işlem parametreleri Tablo 1'de verilmiştir. Solidworks yazılım programı kullanılarak 3D çalışmalar yapılmış olup, elde edilen modele göre alüminyum plaka CNC dikey işleme tezgâhında işlenerek üretim tamamlanmıştır. Isıtma süre ve hacim hesabı aşağıdaki gibi yapılmıştır.
Deneyde kullanılan AISI 304 paslanmaz gövdenin iç hacmi aşağıdaki eşitlikle ifade edilmiştir.

$$
\begin{aligned}
& \mathrm{V}=\mathrm{I} . \mathrm{w} \cdot \mathrm{h}=\mathrm{m}^{3} \\
& \text { L: } 104 \mathrm{~mm} \mathrm{W:} 354 \mathrm{~mm} \mathrm{H:} 270 \mathrm{~mm} \\
& =(10,4) \cdot(35,4) \cdot(27)=9940,32 \mathrm{~cm}^{3}=0,0099 \mathrm{~m}^{3} \approx 10
\end{aligned}
$$

Harcanan enerji tüketimi aşağıdaki eşitlikle ifade edilmiştir.

$$
\begin{array}{r}
\Delta \mathrm{t}=\mathrm{T}_{1}-\mathrm{T}_{2}=95-18=77^{\circ} \mathrm{C} \\
\mathrm{Q}=\mathrm{m} . \mathrm{c} \cdot \Delta \mathrm{t}=(10000 \mathrm{gr}) \cdot(1 \mathrm{cal} / \mathrm{c} \cdot \mathrm{gr}) \times(77)=770 \mathrm{k} \cdot \mathrm{cal}= \\
0,89 \mathrm{kw} \\
=(0,89 \mathrm{kw}) \cdot(860 \cdot \mathrm{cal} / \mathrm{h})=658 \cdot 12 \mathrm{kcal} / \mathrm{h} \\
=\frac{670 \mathrm{kcal}}{658,12 \mathrm{kcal} / \mathrm{h}}=1,01 \mathrm{~h} \\
=(1,01) \cdot(0,77)=0,779 \mathrm{kw} \text { enerji tüketimi } \\
=(10 \mathrm{~kg}) \cdot\left(4,18 \mathrm{kj} / \mathrm{kg} \cdot{ }^{\circ} \mathrm{C}\right)(95-18)^{\circ} \mathrm{C}+ \\
(10 \mathrm{~kg}) \times\left(0,477 \mathrm{kj} / \mathrm{kg} \cdot{ }^{\circ} \mathrm{C}\right)(95-18)^{\circ} \mathrm{C} \\
=3385 \mathrm{kj}
\end{array}
$$

Isıtma süresi aşağıdaki eşitlikle ifade edilebilir.

$$
\begin{aligned}
& \Delta \mathrm{t}=\frac{\mathrm{E}_{\text {in }}}{\mathrm{E}_{\text {transfer }}}=\frac{3385 \mathrm{kj}}{2 \mathrm{kj} / \mathrm{s}}=1692,5 \mathrm{~s}=28 \text { dak. } \\
& \Delta \mathrm{t}=\frac{\mathrm{E}_{\text {in }}}{\dot{\mathrm{E}}_{\text {transfer }}}=\frac{3385 \mathrm{kj}}{1,5 \mathrm{kj} / \mathrm{s}}=2256,6 \mathrm{~s}=38 \text { dak. } \\
& \Delta \mathrm{t}=\frac{\mathrm{E}_{\text {in }}}{\dot{\mathrm{E}}_{\text {transfer }}}=\frac{3385 \mathrm{kj}}{1 \mathrm{kj} / \mathrm{s}}=3385 \mathrm{~s}=57 \text { dak. }
\end{aligned}
$$

Tablo 1. İşlem parametreleri

\begin{tabular}{|c|c|c|c|}
\hline Malzeme & \multicolumn{3}{|c|}{$1050-\mathrm{H} 14$ Alüminyum } \\
\hline Güç & $1 \mathrm{~kW}$ & $1,5 \mathrm{~kW}$ & $2 \mathrm{~kW}$ \\
\hline
\end{tabular}

Deneyde kullanılmış olan farklı güçlerdeki çubuk rezistanslara 220V elektrik akımı verilerek çalıştırılmıştır. Isıtılan suyun sıcaklık ayarı termostat sayesinde kontrol edilmiştir. Farklı güçlerdeki ısıtıcıların her biri için deneyler 3 er defa tekrarlanmış olup, AISI 304 kalite paslanmaz gövdenin içine 10 litrelik şebeke suyu eklenmiştir. Eklenen suyun sıcaklığının $18^{\circ} \mathrm{C}$ olduğu dijital termometre yardımıyla ölçülmüştür. Gövde içindeki su sıcaklığı $18^{\circ} \mathrm{C}$ den $95^{\circ} \mathrm{C}$ ye ne kadar sürede çıktığı deneysel sonuçlarla ölçülmüştür. Suyun $95^{\circ} \mathrm{C}$ çıkarmak bıçak yüzeyindeki bakterilerin ölmesi amaçlanmıştır. Bakterilerin yaşamanı etkileyen faktörlerin arasında sıcaklık önemlidir. $95^{\circ} \mathrm{C}$ sıcaklıkta hemen hemen tüm bakterileri ölürler bu yüzden termostat ayarı $95^{\circ} \mathrm{C}$ olarak ayarlanmaktadır. Aynı zamanda suyun yüksek sıcaklıkta daha az buharlaştığı sıcaklık bu sıcaklıktır. Tablo 2'de bakterilerin gelişim sıcaklıkları verilmiştir. Tablo 2'de gözüktüğü üzere çoğu bakteri için 
Et İşleme Tesislerinde Kullanılan Bıçak Sterilizatörünün Tasarımı Üzerine Deneysel Bir Çalışma

yaşaması zor hatta imkansız olan $95^{\circ} \mathrm{C}$ et içinde bulunan E. coli Salmonella, Listeria, Pseudomonas, Aero- monas hydophila, Enteropathogenic E. coli vb. bakterileri öldürmek ve sayısını 0'a yaklaştırmak için yeterli bir sıcaklıktır (Smith, 1992).

Tablo 2. Sıcaklık gereksinimlerine göre mikroorganizmalar ve gelişme sıcaklıkları

\begin{tabular}{|c|c|c|c|}
\hline Bakteriler & Minimum & Optimum & Maksimum \\
\hline & $(-15)-5$ & $15-20$ & $20-30$ \\
\hline Psikrofil (Zorunlu) & $(-5)-7$ & $25-30$ & $30-40$ \\
\hline Psikrotrof (Fakültatif) & $5-25$ & $30-40$ & $40-50$ \\
\hline Mezofilik & $35-45$ & $45-65$ & $60-90$ \\
\hline Termofilik & $40-45$ & $55-65$ & $70-90$ \\
\hline Zorunlu & $35-40$ & $45-55$ & $60-80$ \\
\hline Fakültatif & \multicolumn{2}{c}{} \\
\hline
\end{tabular}

\section{Deney Malzemelerinin Özellikleri}

Deneyde kullanılan gövde AISI 304 kalite paslanmaz çelik seçilmiştir. AISI 304 kalite paslanmaz malzeme, gövdenin devamlı suyla temasının olması ve korozyon direncinin fazla olmasından dolayı tercih edilmiştir. Gövde altına yerleştirilen alüminyum ısıtıcı plakanın tercih edilme sebebi ise ısı iletkenliğinin yüksek olmasıdır. Deneyde kullanılan AISI 304 kalite paslanmaz ve 1050-H14 Alüminyum malzemelerinin kimyasal verileri Tablo 3 ve Tablo 4'de verilmiştir. Isıl iletkenlik katsayıları ise Tablo 5 ' de verilmiştir.

Tablo 3. $1050 \mathrm{H} 14$ alüminyum kimyasal özellikleri (\%)

\begin{tabular}{|c|c|c|c|c|c|c|c|}
\hline $\mathrm{Fe}$ & $\mathrm{Si}$ & $\mathrm{Zn}$ & $\mathrm{Ti}$ & $\mathrm{Mg}$ & $\mathrm{Mn}$ & $\mathrm{Cu}$ & $\mathrm{Al}$ \\
\hline 0,4 & 0,25 & 0,07 & 0,05 & 0,05 & 0,05 & 0,05 & 99,5 \\
\hline
\end{tabular}

Tablo 4. AISI 304 Kalite paslanmaz kimyasal özellikleri (\%)

\begin{tabular}{|c|c|c|c|c|c|c|}
\hline $\mathrm{C}$ & $\mathrm{Mn}$ & $\mathrm{P}$ & $\mathrm{S}$ & $\mathrm{Si}$ & $\mathrm{Cr}$ & $\mathrm{Ni}$ \\
\hline 0,0008 & 0,02 & 0,00045 & 0,0003 & 0,0075 & 0,2 & 0,1 \\
\hline
\end{tabular}

Tablo 5. Deney malzemelerinin ısı iletkenlik kat sayıları $(\lambda)$

\begin{tabular}{|c|c|}
\hline Malzeme & Isıl İletkenlik Kat Sayısı W/m.K \\
\hline $\begin{array}{c}\text { AISI 304 Kalite Paslanmaz (2 } \\
\text { mm) }\end{array}$ & $17.2 \mathrm{~W} / \mathrm{m} . \mathrm{K}$ \\
\hline 1050-H14 Alüminyum & $237 \mathrm{~W} / \mathrm{m} . \mathrm{K}$ \\
\hline
\end{tabular}

Deney kalıbı olan alüminyum plaka CNC dik işleme tezgahında hassas olarak $100 \times 337 \mathrm{~mm}$ ölçülerinde talaşlı imalat işlemi yapılmıştır. Daha sonra çubuk rezistanslar alüminyum plaka içerisine açılan kanallara konumlandı- rılmış olup, Şekil 1'de görselleri verilmiştir. Ani su ısıtıcısının genel gösterimini de Şekil 2 verilmiştir. Alüminyum plakanın konumlandığı AISı 304 kalite gövde CNC lazer ve CNC abkant tezgahı yardımı ile hazırlanmıştır (URL1, 2021; URL-2, 2021). 
Et İşleme Tesislerinde Kullanılan Bıçak Sterilizatörünün Tasarımı Üzerine Deneysel Bir Çalışma

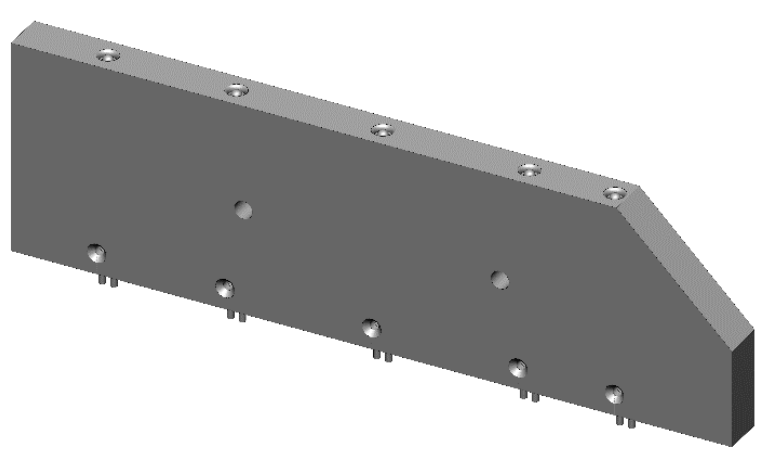

Şekil 1. Isıtıcı alüminyum plaka

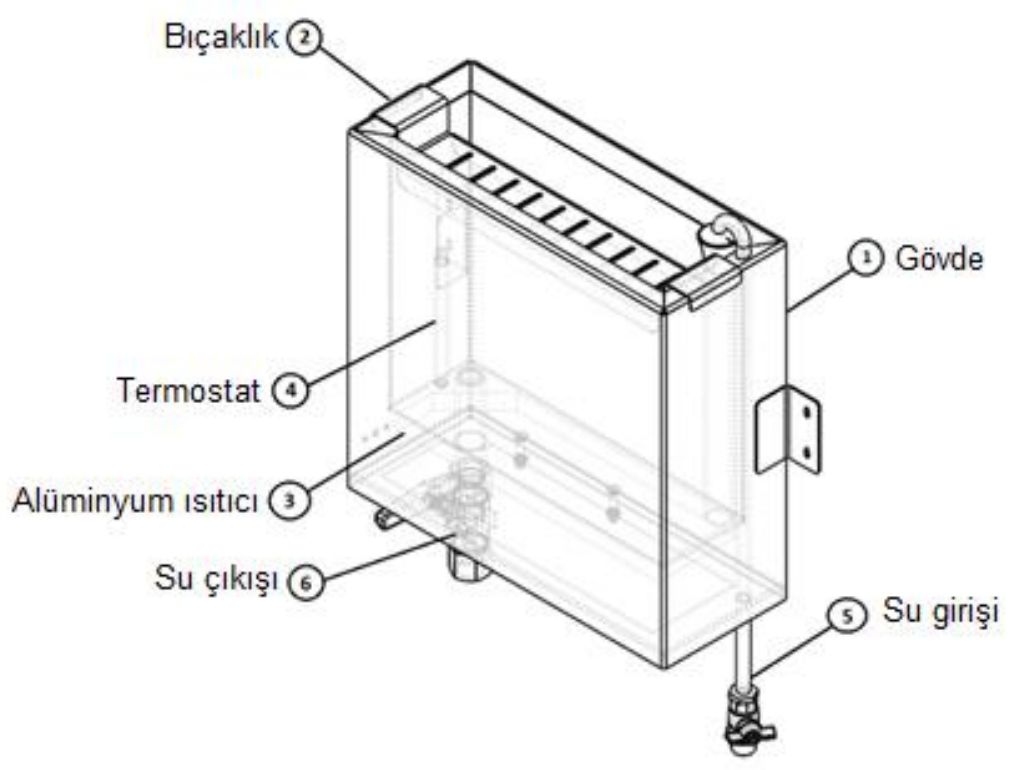

Şekil 2. Ani su ısıtıcı

\section{Deney Düzeneği}

Üretilen ürün makine emniyet yönetmeliğine göre üretilmiştir. Şekil 3'de gösterilmiştir (2006/42/AT)(TS EN 60204-1:2011). 


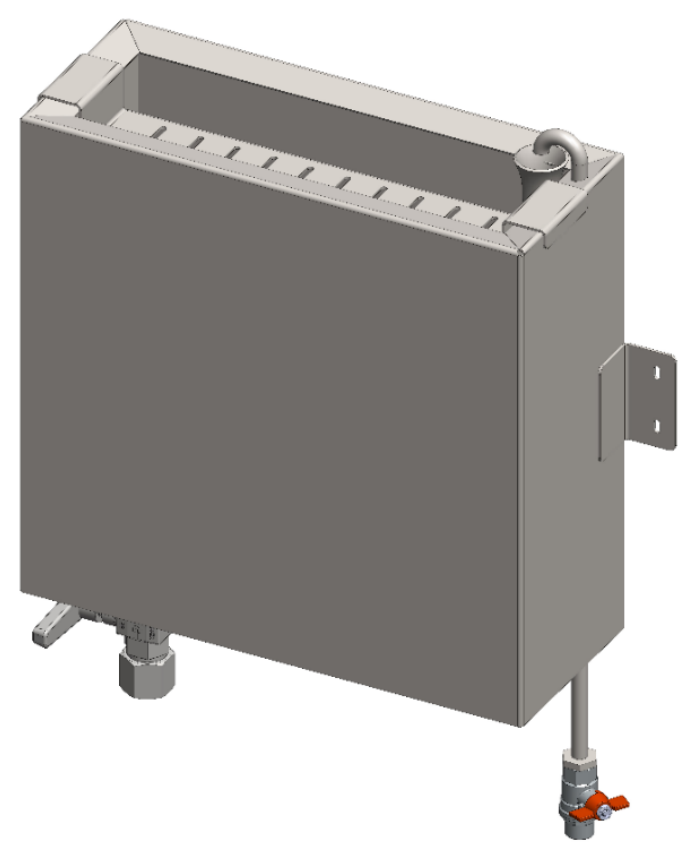

Şekil 3. Deney düzeneği

\section{BULGULAR VE TARTIŞMA}

Deney işleminde $1 \mathrm{~kW}, 1,5 \mathrm{~kW}$ ve $2 \mathrm{~kW}$ güçlerinde enerji verilerek ısıtma işlemi yapılmıştır. Her parametre için üçer adet olacak şekilde deneme ölçümleri yapılmıştır. Deneyler 220V elektrik enerjisi verilerek yapılmış olup, ısı kontrolü ise termostat yardımı ile gerçekleşmiştir.
Gövde içerisine 10 litrelik şebeke suyu eklenmiştir. Suyun $18^{\circ} \mathrm{C}$ den $95^{\circ} \mathrm{C}$ ye çıkarılma sürelerinin ortalaması alınmıştır. Tablo 6'de her parametrenin değerleri verilmiştir.

Tablo 6. Alüminyum ısıtıcı plakanın deneysel sonuçları

\begin{tabular}{|c|c|c|c|c|}
\hline & \multicolumn{4}{|c|}{ Süre (Dakika) } \\
\hline Güç & Deney 1 & Deney 2 & Deney 3 & Ortalama \\
\hline $1 \mathrm{~kW}$ & 57 & 55 & 58 & 57 \\
\hline $1,5 \mathrm{~kW}$ & 38 & 36 & 39 & 38 \\
\hline $2 \mathrm{~kW}$ & 30 & 27 & 28 & 28 \\
\hline
\end{tabular}

Tablo 5'de genel olarak görünen sürelere bakıldığında güç arttıkça ısıtma süresinin azaldığı gözlenmektedir. Minimum süre $2 \mathrm{~kW}$ gücünde ve maksimum süre ise 1
kW gücündeki çubuk rezistansların olduğu gözlenmektedir. Tablodaki sonuçlar yukarıda hesaplamalarla da doğrulaması yapılmıştır. 


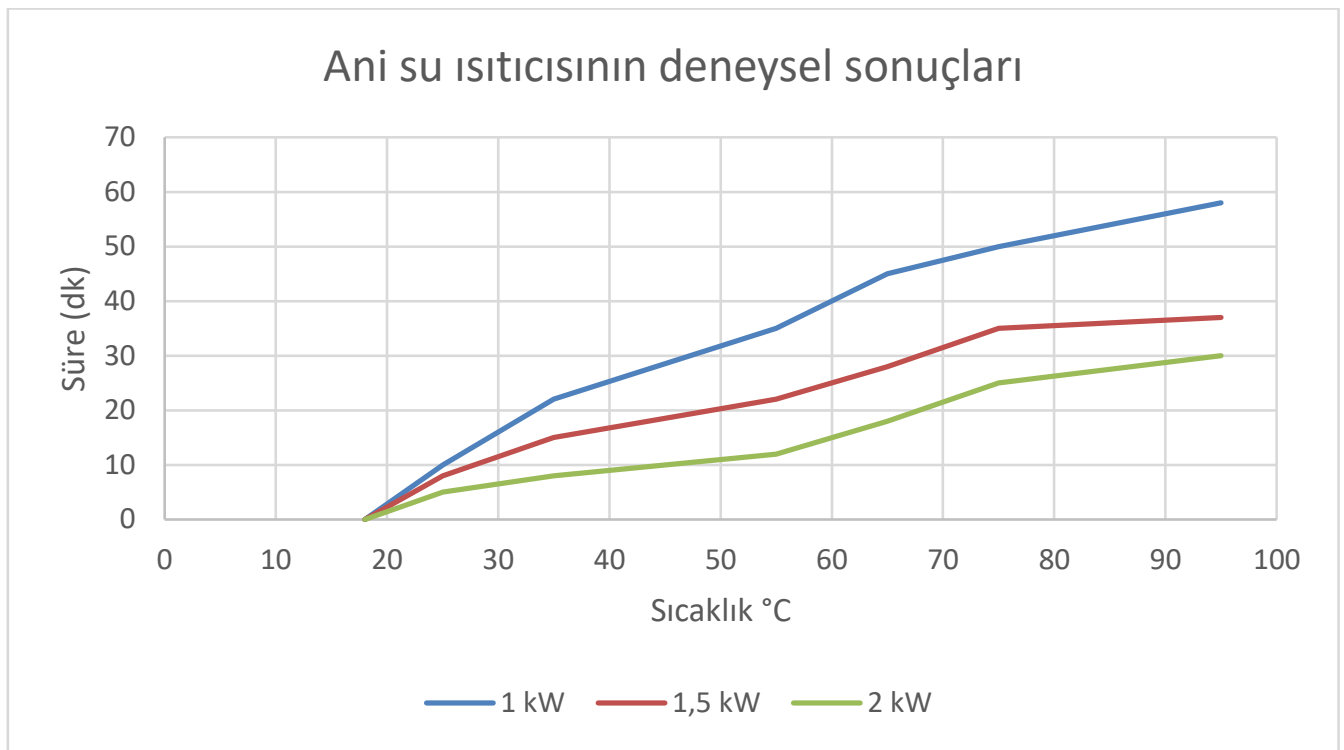

Şekil 4. Ani su ısıtıcısının farklı güçlerdeki çubuk rezistanslarının ısıtma süre grafiği

Şekil $4^{\prime}$ 'de görüldüğü üzere suyu $18^{\circ} \mathrm{C}$ den $95^{\circ} \mathrm{C}$ ye en kısa sürede çıkaran güç $2 \mathrm{~kW}$ olduğu tespit edilmiştir. Verilen güç arttıkça ısınma süresi azaldığı gözlenmektedir. Güç ile süre arasında ters orantı bulunduğu deneylerle tespit edilmiştir.

\section{SONUÇLAR}

Ani su ısıtıcısı olarak tasarlanan bıçak sterilizatörünün genel amacı şebekeden gelen suyu çubuk rezistanslar ve alüminyum plaka vasıtasıyla ısıtarak, istenilen sıcakıı̆a ulaşmasını sağlar. Bıçaklar bıçaklık bölmesine takılarak her işlemden önce dezenfekte edilir. Bıçak sterilizatörünün tabanında bulunan alüminyum plakaya sabitlenmiş çubuk rezistanslar sayesinde su ısıtılmaktadır. Sterilizatörün içerisinde bulunan termostat çubuğu ile su sıcaklığını gövde de bulunan ısı ayar butonu yardımıyla istenilen ${ }^{\circ} \mathrm{C}$ derecede su Isısı ayarlanabilir.

İşleme alanında bulunan personellerin her işlem sonunda bıçakları mekanizmaya takarak dezenfekte etmesini sağlamaktadır. Su seviyesi mekanizmadan taşmayacak şekilde ürünün altında bulanan vanalar yardımı ile doldur boşalt yapılmalıdır;

I. Deney sonuçlarından elde edilen grafikler incelendiğinde, çubuk rezistansların güçlerin artmasıyla birlikte suyu kaynama süresinin azaldığı görülmektedir. Maksimum süre $1 \mathrm{~kW}$ gücünde rezistansta elde edilirken, minimum süre ise $2 \mathrm{~kW}$ gücünde rezistansta elde edilmiştir. Elde edilen sonuçlar literatür ile örtüşmektedir.
II. Alüminyum plakalar için 3er adet yapılan deney sonuçlarında birbirine çok yakın deney süreleri çıkmıştır.

III. AISI 304 kalite paslanmaz gövdenin altına konumlandırımış olan 1050-H14 Alüminyum ısıyı homojen bir şekilde suya ilettiği gözlenmiştir.

IV. Yapılan bilimsel hesaplamalarda görüldüğü üzere deney sonuçları örtüşmektedir.

\section{KAYNAKLAR}

Aktaş, B. (2016). Makine mühendisliğinde malzeme seçimi ders notları.

Akbulut, P. (2010). Yalova ilinde faaliyet gösteren hazır yemek üretim yerlerinde çalışan personelin hijyen bilgi düzeyi ile üretilen yemeklerin mikrobiyolojik kalitesi arasındaki ilişkinin belirlenmesi. Yüksek Lisans Tezi, Namık Kemal Üniversitesi Fen Bilimleri Enstitüsü, Tekirdağ.

Atasever, M. (2000). Besin işyerlerinde: Hijyen, besinlerin hazırlanması ve muhafazası. Yüzüncü Yıl Üniversitesi Veterinerlik Fakültesi Dergisi, 11(2): 117-122.

Batchelor, R. (1994). Not looking at kettles. Interpreting objects and collections. In: Interpreting Objects and Collections. Pearce, S. (ed), Routledge, London, UK, 1-3.

Bilici, S. (2007). Kişisel hijyeni geliştirme ve yaygınlaştırma programı. Sağlık Bakanlığı Temel Sağlık Hizmetleri Genel Müdürlüğü Beslenme ve Fiziksel Aktivite Daire Başkanlığı, Ankara.

Bilici, S. (2008). Toplu beslenme sistemleri çalışanları için hijyen el kitabı. Klasmat Matbaacılık, No: 726, Ankara.

Boot, M., Cairncross, S. (1993). Actions speak: the study of hygiene behaviour in water and sanitation projects. IRC, The Hague, The Netherlands.

Cengel, Y. A., Ghajar, A. J. (2014). Numerical methods in heat conduction. Heat Mass Transfer (Isı ve Kütle Transferi), Çev: Vedat Tanyıldızı, 3. Baskı, Güven Kitapevi, İzmir. 
Çakar, D. (2021). Rezistansla ısıtılan termoform kalıp kurutma sistemlerinin kararlı hal koşullarında ısı dağılımı analizi, Pamukkale Üniversitesi, Fen Bilimleri Enstitüsü, Otomotiv Mühendisliği Anabilim Dalı, Yüksek Lisans Tezi, 91 s, Denizli.

Çengel, Y.A. (2015), Termodinamik: mühendislik yaklaşımıyla. Palme Yayıncılık, 165-218.

Garayoa, R., Vitas AI, Díez-Leturia, M., García-Jalón, I. (2011). Food safety and the contract catering companies: Food handlers, facilities and HACCP evaluation. Food Control, 22: 2006-2012.

Motarjemi, Y.(2016). The starting point: What is food hygiene? In: Handbook of Hygiene Control in the Food Industry. Lelieveld, H.L., Holah, J., Gabric, D. (eds.), Woodhead Publishing.

Park, G., Lee, C. (2008). Experimental and numerical study on Indentation, 560: 127-132.

Resmi Gazete (2009). 2006/42/AT Makine Emniyet Yönetmeliği, 03.03.2009 Tarih ve 27158 Sayılı Resmi Gazete.

Sayın, M. (2007). Siirt ilinde hizmet veren değişik birimlerden (lokanta, kafeterya gibi) alınan örneklerden patojen mikroorganizmaların aranması. Adnan Menderes Üniversitesi, Sağlık Bilimleri Enstitüsü, Veteriner Fakültesi, Mikrobiyoloji Anabilim Dalı, Yüksek Lisans Tezi, $35 \mathrm{~s}$, Aydın.

Sharif, L., Obaidat, M. M. Al-Dalalah, M. R. (2013). Food hygiene knowledge, attitudes and practices of the food handlers in the military hospitals. Food and Nutrition Sciences, (4): $245-251$.
Smith, M. (1992). Destruction of bacteria on fresh meat by hot water. Epidemiology and Infection, 109(3): 491-496.

Sökmen, A. (2003). Ağırlama endüstrisinde yiyecek ve içecek yönetimi. Detay Yayıncılık, No: 44, Ankara.

Tayar, M., Yarsan, E. (2014). Gıda kaynaklı tehlikeler. In: Veteriner Halk Sağlığı. Tayar M, Yarsan E. (eds.), Dora Basım-Yayın Dağıtım Ltd. Şti, Bursa.

TS EN 60204-1 (2018). Makinelerde Güvenlik - Makinelerin Elektrik Donanımı - Bölüm 1: Genel Kurallar.

Ural, D. (2007). Konaklama işletmelerinde çalışan personelin kişisel hijyen bilgileri ve uygulamaları üzerine bir araştırma. Yayınlanmamış Yüksek Lisans Tezi, Gazi Üniversitesi Eğitim Bilimleri Enstitüsü, Aile Ekonomisi ve Beslenme Eğitimi Anabilim Dalı, $110 \mathrm{~s}$, Ankara.

URL-1 (2021). Baykal Rezistans. https://www.baykalrezistans.com/urunler/fisek-rezistanslar.html (Erişim Tarihi: 21.04.2021).

URL-2 (2021). Isı Form Rezistans. https://www.isiformrezistans.com/teknik-45-isi-hesaplama.html (Erişim Tarihi: 21.04.2021).

Yaman, M., Özgen, L. (2007). Üniversite öğrencilerinin yurtlarındaki besin hijyeni yaklaşımları ve besin hazırlama uygulamaları. Gazi Universitesi Endüstriyel Sanatlar Eğitim Fakültesi Dergisi, (20): 28-38. 